\title{
Nanobiotechnological Approaches to Enhance Potato Resistance against Potato Leafroll Virus (PLRV) Using Glycyrrhizic Acid Ammonium Salt and Salicylic Acid Nanoparticles
}

\author{
Tahsin Shoala ${ }^{1, *}$, Ahmed A. Al-Karmalawy ${ }^{2}{ }^{1}$, Mousa O. Germoush ${ }^{3}$, Salha M. ALshamrani ${ }^{4}$, \\ Mohamed A. Abdein ${ }^{5}$ iD and Nabil S. Awad 1,6 \\ 1 Environmental Biotechnology Department, College of Biotechnology, Misr University for Science and \\ Technology, Giza 12563, Egypt; nabilfaris151@yahoo.com \\ 2 Department of Pharmaceutical Medicinal Chemistry, Faculty of Pharmacy, Horus University-Egypt, \\ New Damietta 34518, Egypt; akarmalawy@horus.edu.eg \\ 3 Biology Department, College of Science, Jouf University, Sakaka 72341, Saudi Arabia; mogermoush@ju.edu.sa \\ 4 Department of Biology, College of Science, University of Jeddah, Jeddah 21959, Saudi Arabia; \\ smalshmrane@uj.edu.sa \\ 5 Biology Department, Faculty of Arts and Science, Northern Border University, Rafha 91911, Saudi Arabia; \\ abdeingene@yahoo.com \\ 6 Department of Genetics, Faculty of Agriculture and Natural Resources, Aswan University, \\ Aswan 81528, Egypt \\ * Correspondence: Tahsen.shoala@must.edu.eg
}

\section{check for} updates

Citation: Shoala, T.; Al-Karmalawy, A.A.; Germoush, M.O.; ALshamrani, S.M.; Abdein, M.A.; Awad, N.S. Nanobiotechnological Approaches to Enhance Potato Resistance against Potato Leafroll Virus (PLRV) Using Glycyrrhizic Acid Ammonium Salt and Salicylic Acid Nanoparticles. Horticulturae 2021, 7, 402. https:/ / doi.org/10.3390/horticulturae7100402

Academic Editor: Jiatao Xiè

Received: 31 August 2021

Accepted: 7 October 2021

Published: 14 October 2021

Publisher's Note: MDPI stays neutral with regard to jurisdictional claims in published maps and institutional affiliations.

Copyright: (c) 2021 by the authors. Licensee MDPI, Basel, Switzerland. This article is an open access article distributed under the terms and conditions of the Creative Commons Attribution (CC BY) license (https:// creativecommons.org/licenses/by/ $4.0 /)$.
Abstract: The present research was aiming to study In-Silico the effect of Glycyrrhizic Acid ammonium salt (GAS) and Salicylic acid (SA) on the coat protein of potato leafroll virus (PLRV). In addition, in-vitro studying the effect of (GAS NPs) and Salicylic acid (SA NPs) nanoparticles at concentrations $0.15,0.30,1.25$ and $2.5 \mathrm{mM}$, respectively, to control, decline or reduce the presence of PLRV in potato plants Solanum tuberosum L. selena. (GAS NPs) and (SA NPs) were applied in the MS medium at concentrations $0.15,0.30,1.25$ and $2.5 \mathrm{mM}$, respectively. Results revealed that, enhancement or decline the PLRV according to the initiation of specific pathways. The expression level of Kinase 3 gene increased significantly due to the two used concentrations of GAS NPs. While the expression of callose gene was upregulated significantly in response to treatment of PLRV infected plant with (GAS NPs) with concentration $(0.30 \mathrm{mM})$. Treatment with (SA NPs) caused upregulation significance only of callose gene at $(2.5 \mathrm{mM})$ concentration. The molecular modeling results of used compounds (glycyrrhizic acid ammonium salt and salicylic acid) showed highest score of binding and the best rms define value with a very good binding mode and perfect interactions with amino acids of the three subunits (A, B and C) forming the protein coat of leaf roll virus. Glycyrrhizic acid ammonium salt and salicylic acid nanoparticles could be perfect solution to produce potato plant free virus in-vitro. Further larger studies are needed to investigate the role of the studied compounds in vivo.

Keywords: nanoparticles; glycyrrhizic acid ammonium salt; salicylic acid; potato leafroll virus (PLRV); molecular docking; kinase kinase 3 gene; callose synthase 2 gene

\section{Introduction}

Potato crop is recognized as one of the most valuable crops worldwide. Potato crop production has increased remarkably during the last few decades in comparison with major staple crops. Potato plants could be infected with many types of viruses.

Despite the fact that over 50 distinct viruses and one viroid have been reported as potato viral infections across the world, only a few of them cause significant global losses. Potato leafroll virus (PLRV) is considered now as one of the most destructive viruses of potato worldwide, Tuber yield losses for infected potato plants with PLRV can reach more than $80 \%$. 
Many viruses cause economic losses in addition to yield decrease by compromising potato quality, notably by producing internal and surface tuber necrosis. PLRV may induce tuber vascular system necrosis, often known as "net necrosis" [1]. PLRV is consistently spread, while other major potato viruses, such as potato virus Y (PVY), potato virus A, potato virus $\mathrm{S}$ and potato virus $\mathrm{M}$, are not [2].

\subsection{Glycyrrhizic Acid}

Glycyrrhizic acid (GA) is a key bioactive ingredient found in licorice, derived from the rhizomes and roots of Glycyrrhiza glabra [3]. Licorice has been widely used as a herbal medication to treat a variety of illnesses, including antiviral [4], antibacterial [5], antifungal [6], antioxidant [7], anticancer [8], antiulcer [9], anti-inflammatory [10], antiallergic [11] and hepatoprotective [12]. Glycyrrhizic acid can also be utilized as Glycyrrhizic acid ammonium salt.

\subsection{Salicylic Acid (SA)}

Salicylic acid (SA) is a phenolic molecule that has been linked to plant development and hormonal control. SA, as a phytohormone, regulates growth and a variety of developmental processes, including photosynthesis, mineral ion uptake and absorption, enzyme activity and stress tolerance $[13,14]$. The significance of SA in increasing resistance to abiotic stressors has been extensively established $[13,15]$. SA increases plant resistance to metal toxicity harmful metals [16]. SA increases stress tolerance by increasing antioxidant function and glycine betaine accumulation, resulting in photosynthetic protection [17].

Nanomaterials could be applied successfully to manage or control many plants pathogenic microorganisms. Transmuting natural substances to nano-size could be applied efficiently to manage phytopathogens without harming the environment and human being. Natural nanoparticles could improve the natural nanoproduct activities against phytopathogens; enhance plant immunity against biotic and abiotic stresses, upsurge the shelf life of fruits and vegetables at room temperature, reduce the consequences and toxicity of pesticide use, and reduce the negative impact of employing hazardous metallic nanoparticles [18].

\subsection{Plant Defense-Related Genes}

Under stress circumstances, such as pathogen infection, callose builds fast and dramatically, clogging sieve plates, decreasing phloem functioning and interfering with glucose transfer from source organs (mostly leaves) to sink organs (roots, flowers, fruits). Callose Synthase (CalS) is the most important enzyme for callose synthesis. In this case, 12 callose synthase (AtCalS) genes in Arabidopsis thaliana have been discovered and described [19]. Among these, AtCalS7 has been linked to the production of callose in the phloem sieve plate in response to stressors [20].

The analysis of $A$. thaliana calS7 mutants revealed that the holes in the sieve plate were malformed, with reducing or blocking of the pores [20]. Under these circumstances, the phloem became non-functional, and starch accumulated in the leaves [21]. Furthermore, other AtCalS have been implicated in plant defensive responses against phytopathogen invasion, including AtCalS2, AtCalS5, AtCalS8 and AtCalS12. After salicylic acid (SA) treatment and Hyaloperonospora arabidopsis infection, the expression of AtCalS2, AtCalS5 and AtCalS8 genes induced in Arabidopsis rosette leaves, potentially playing a role in callose accumulation at plasmodesmal channels as a strategy to alter plasmodesmal permeability under pathogen infection [22,23]. Mitogen-activated protein kinase (MAPK) cascades are highly preserved signaling modules that work downstream of receptors/sensors to transform extracellular inputs into intracellular responses in eukaryotes. Plant MAPK cascades perform critical functions in signaling plant defense against pathogen assault. These findings shed light on the molecular processes underlying MAPK roles in disease resistance in plants. MAPK cascades have also emerged as sites of plant-pathogen conflict. MAPK activation is one of the first signaling processes that occurs when plants detect 
pathogen/microbe-associated molecular patterns (PAMPs/MAMPs) and pathogen effectors. MAPK cascades are connected in signaling multiple innate immunity, along with the biosynthesis/signaling of plant stress/defense hormones, reactive oxygen species (ROS) generation, stomatal closure, defense gene activation, phytoalexin biosynthesis, cell wall reinforcing and hypersensitive response (HR) cell death. Pathogens, on the other hand, use effectors to inhibit plant MAPK activation and downstream defensive responses, therefore promoting pathogenesis [24].

\subsection{Docking Studies}

Simulating nature using computational molecular modelling is one of the most significant and latest ways to investigating the activity of a specific molecule. Various computer software are used in this procedure to test molecules into the specified binding sites in three-dimensional models of the protein targets. The interaction of the tested substances with the binding site may be measured by applying physics-based equations to compute binding affinities. The best compounds were then evaluated experimentally on living models to establish their true affinity and efficacy (such as stopping viral infectivity).

Molecular docking as a very promising and accurate tool to explain and confirm in vitro results is used to investigate the binding modes and energies of both glycyrrhizic acid and salicylic acid against potato leaf roll virus.

PLRV belongs to the Polerovirus genus, which belongs to the Luteoviridae family [25]. The PLRV genome is a $5.8 \mathrm{~kb}$ monopartite, single-stranded positive-sense RNA encased in isometric particles. The PLRV genome has eight open reading frames (ORFs), each separated into two parts by a non-coding region. Three 59-proximal ORFs that are produced by genomic RNA encode proteins related in viral replication and gene silencing suppression [26]. Five additional ORFs are expressed by translating two subgenomic RNAs (sgRNAs). Translation of two subgenomic RNAs results in the transcription of five additional ORFs (sgRNAs). SgRNA1 encodes two structural proteins, the CP and RTD, as well as a $17 \mathrm{kDa}$ mobility protein (P17) [27]. sgRNA2 encodes two 39-proximal proteins with unknown functions [28].

Our hypothesis is studying the ability of nanoparticles to manage PLRV In-Silico and in-vitro. Our research study confirmed that molecular docking can guide researchers to choose the effective material against different plant pathogen, also, speed up in-vitro and in-vivo application. The importance of our work is introducing the key solution to manage PLRV and the same idea could be applied in all different plant viruses. Our main goal is to use safe and ecologically friendly therapies that do not hurt people or the environment.

\section{Materials and Methods}

\subsection{Docking Studies}

Docking studies were conducted using the MOE 2019 drug design program to evaluate the activity of the two tested compounds against the Potato Leaf Roll viral protein coat, which has been linked to many viral characteristics such as serological properties, transmission specificity [29], cross-protection and mutual exclusion [30].

\subsection{Tested Compounds Optimization}

The examined materials (Glycyrrhizic acid ammonium salt and Salicylic acid) were obtained from the PubChem website (https:/ / pubchem.ncbi.nlm.nih.gov/, 21 April 2020). The studied materials were submitted to energy minimization after their structures and formal charges on atoms were verified by 2D depiction. Automatically, the partial charges were computed. Our two compounds were imported into the same database and exported as an MDB file for use in docking calculations against the target viral protein coat.

\subsection{Target Potato Leaf Roll Viral Protein Coat Active Site Optimization}

The X-ray patterns of the unliganded potato leaf roll viral protein capsid were obtained from the Protein Data Bank through the internet (http:/ /www.rcsb.org/, 21 April 2020 
PDB code 6SCO) and were composed of the two tested materials. All of the processes for preparing the target protein for docking experiments were completed. Hydrogen atoms with standard 3D geometry were added to the system, automated correction was used to check for any faults in the atom's connection and kind, and the potential of the receptor and its atoms was fixed. Using all default elements, Site Finder was used to find the biggest active site (defined as the central acidic patch which is the central core located in between the three subunits A, B and C creating the pyramidal shaped viral protein coat) ${ }^{2}$ in the target viral protein. Dummy atoms were produced from the site analyzer of the pocket [31].

\subsection{Docking of the Tested Molecules to Viral Main Protein Coat Binding Site}

Docking was carried out on the previously described database, which was made up of the two tested compounds. In general, the following technique was used: the pre-prepared protein active site file was loaded, and the dock tool was launched as a generic docking procedure. The program requirements were changed such that fake atoms were used as the docking site, triangle matcher was used for placement and London dG was used for scoring. The rigid receptor was used as the refining approach, while the GBVI/WSA dG was used as the scoring mechanism for selecting the best postures. The scoring methods were reset to their default settings. The MDB file containing two ligands was imported, and general dock calculations were automatically performed. After the docking procedures were completed, the acquired postures were examined and the best ones exhibiting the best ligand-protein interactions were chosen and saved for energy calculations.

\subsection{Sample Collection}

Infected tissue cultured potato plants with Potato Leaf Roll Virus PLRV were kindly provided by Dr. Ahmed Abd Al-Maksud, Genetic engineer institute, Sadat University, Egypt. Parts from the infected tissue cultured plants harvested and excised under sterilized condition in vitro cultured. Sterilization occurred by immersion potato plantlets for several seconds in $70 \%$ ethanol followed by rinsing three times in sterile distilled water under laminar airflow cabinet [32].

\subsection{Media Preparation}

Murashige and Skoog [33] (MS) salts, $\mathrm{NaH}_{2} \mathrm{PO}_{4} \cdot 2 \mathrm{H}_{2} \mathrm{O}(221 \mathrm{mg} / \mathrm{L})$, thiamine $\mathrm{HC} 1$ $(0.4 \mathrm{mg} / \mathrm{L})$, inositol $(100 \mathrm{mg} / \mathrm{L})$, sucrose $(30 \mathrm{~g} / \mathrm{L})$, agar $(8 \mathrm{~g} / \mathrm{L}), \mathrm{pH}$ adjusted to 5.8 were used to make the regeneration medium. The medium is sterilized by autoclaving it for about $20 \mathrm{~min}$ at $15 \mathrm{psi}$ and $121^{\circ} \mathrm{C}$. The autoclaved MS media was cooled to $45-50{ }^{\circ} \mathrm{C}$ before being put into screw cap jars with $30 \mathrm{~mL}$ of the MS medium. The culture glass screw cap jars were then incubated at 20-21 in a 16-h photoperiod with a light intensity of 2000 lux. Potato plantlets were regenerated and reproduced in Culture glass screw cap jars using stem cuttings on MS basal medium [34]. Natural materials were prepared at different concentrations, then sterilized by using $0.2 \mu \mathrm{m}$ Millipore and added to MS medium after autoclaving and cooling down to $40-50{ }^{\circ} \mathrm{C}$.

\subsection{Glycyrrhizic Acid Ammonium Salt Nanoparticles Preparation}

Glycyrrhizic acid ammonium salt (CAS number: 53956-04-0) bought from SigmaAdrich, St. Louis, MO, USA, $0.1 \mathrm{mg}$ Glycyrrhizic acid at room temperature $\left(20-25^{\circ} \mathrm{C}\right)$, $1 \mathrm{~mL}$ absolute ethanol was dissolved in ammonium salt, which was then refrigerated $\left(4^{\circ} \mathrm{C}\right)$. Glycyrrhizic Acid ammonium salt concentrations of 0.15 and $0.30 \mathrm{mM}$ were used [35].

\subsection{Preparation and Characterization of SA Nanoparticles}

SA was bought from Sigma-Adrich (CAS number: 20283-92-5), and $10 \mathrm{mg}$ of SA were dissolved in $10 \mathrm{~mL} 100 \%$ ethanol and sonicated for an hour at ambient temperature $\left(25^{\circ} \mathrm{C}\right)$ using an ultrasonic power and frequency of $50 \mathrm{kHz}$ (XUBA3Analogue Ul-ta-sonic Bath, Grant Company, Saint Joseph, MO, USA). SA-NPs were used at two concentrations: 1.25 and $2.5 \mathrm{mM}$ [36]. 


\subsection{Characterization of Nanomaterials by Using Dynamic Light Scattering (DLS)}

At room temperature, the distribution and size of GAS-NPs and SA-NPs were measured using a dynamic light scattering technique using a Zetasizer Nano ZS (Malvern Instruments, Malvern, UK). $30 \mathrm{~L}$ of nanoparticles were diluted with $3 \mathrm{~mL}$ of water at $25{ }^{\circ} \mathrm{C}$ before to measurement. The mean of the Z-average of three separate batches of nanoparticles was used to calculate particle size.

\subsection{RNA Extraction}

The total RNA has been extracted from infected tissue cultured potato plantlets Utilizing the EZ-10 Spin Column Total RNA Minipreps Super kits, then RNA purified according to the protocol of Thermo Scientific GeneJET Plant RNA Purification Mini Kit. Then, extracted RNA has been applied as a template for cDNA synthesis [37].

\subsection{Primer Design and Gene Expression}

QRT-PCR primers were designed using Allele ID 7.7 software to achieve optimal specificity and efficiency during qPCR amplification under a defined set of reaction conditions. In this work, actin (ACT) was employed as a reference gene (see Table 1). At different time points, ACT1 provided consistent expression levels. The primers were created using Table 1 lists the primers for the genes utilized in the gene expression research. The real-time fluorescence quantitative PCR was performed using a real-time fluorescence quantitative PCR equipment (Agilent, Santa Clara, CA, USA). In addition to the non-template control, each sample was subjected to three biological replicates (NTC).

ach PCR reaction contained $2.5 \mathrm{~L}$ of cDNA (save for the NTC and cDNA controls), $10 \mathrm{~L}$ of SYBR Green PCR Master Mix (HERA SYBR ${ }^{\circledR}$ Green Master Mix (2x), Willowfort-UK), $0.5 \mathrm{M}$ of each forward and reverse primer and RNase-Free water to a final volume of $20 \mathrm{~L}$. The PCR conditions were as follows: $95^{\circ} \mathrm{C}$ for $2 \mathrm{~min}$, followed by 40 cycles of $95^{\circ} \mathrm{C}$ for $20 \mathrm{~s}$, $60^{\circ} \mathrm{C}$ for $20 \mathrm{~s}$ and $72{ }^{\circ} \mathrm{C}$ for $20 \mathrm{~s}$. Fluorescence monitoring was performed at the conclusion of each cycle, followed by a 15 -min period at $95{ }^{\circ} \mathrm{C}$ for melting temperature analysis. The level of gene expression was determined using the approach of $2^{-\Delta \Delta \mathrm{CT}}$ [38]. For qPCR data standardization, the expression of the pepper ubiquitin-conjugating protein was utilized as a reference gene.

Table 1. Kinase kinase 3, Callose synthase and the reference gene (ACT) for QRT-PCR.

\begin{tabular}{|c|c|c|c|c|}
\hline Primer Name & Accession No. & Primer Sequence & bp & $\mathrm{T}\left({ }^{\circ} \mathrm{C}\right)$ \\
\hline Kinase Kinase 3 & XM_006351467.2 & $\begin{array}{c}\text { F 5'-TTA CAT GTC GCC GGA ACG AA- } 3^{\prime} \text { R } \\
5^{\prime} \text {-CAC TCA AAC AGT GCA AGC CC- } 3^{\prime}\end{array}$ & 84 & $\begin{array}{l}58.4^{\circ} \mathrm{C} \\
60.5^{\circ} \mathrm{C}\end{array}$ \\
\hline Callose synthase 2 & XM_015314276.1 & 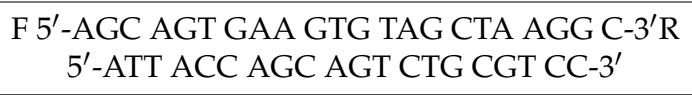 & 139 & $\begin{array}{l}62.1^{\circ} \mathrm{C} \\
60.5^{\circ} \mathrm{C}\end{array}$ \\
\hline ACTIN & X55749 & $\begin{array}{c}\text { F 5'-GCT TCC CGA TGG TCA AGT CA-3'R } \\
5^{\prime} \text {-GGA TTC CAG CTG CTT CCA TTC-3' }\end{array}$ & 101 & $\begin{array}{l}60.5^{\circ} \mathrm{C} \\
61.3^{\circ} \mathrm{C}\end{array}$ \\
\hline
\end{tabular}

\subsection{RT-PCR Detection}

According to the kit used for the RT-PCR, the molecular diagnostic to identify the presence or absence of PLRVvirus is: (VersoTM) one step RT-PCR kit (Thermo scientific, Waltham, MA, USA, cat. No. AB 1454/V6/1107). The isolated RNA was utilized as a template for a one-tube RT-PCR amplification experiment with the Verso TM one-step RT-PCR kit with PLRV-specific primers. PLRV-F: 5'AATAGAATTCTAATGAGTACGGTCGTGGTTARAGG $3^{\prime}$ and PLRV-R:5'AAAACCATGGCTATYTGGGGTTYTGCARAGCYAC $3^{\prime}$ RT-PCR was performed in $25 \mu \mathrm{L}$ total volume containing $4.75 \mu \mathrm{L}$ of nuclease-free water, $3 \mathrm{ng} / \mu \mathrm{L}$ of total RNA, $12.5 \mu \mathrm{L}$ of one step PCR master mix, $3 \mu \mathrm{L}$ of $10 \mu \mathrm{M}$ of each primer, $0.5 \mu \mathrm{L}$ Verso enzyme mix and $1.25 \mu \mathrm{L}$ RT-Enhancer. RT reaction started with incubation at $50 \mathrm{C}$ for $15 \mathrm{~min}$, followed by denaturation at $95{ }^{\circ} \mathrm{C}$ for $5 \mathrm{~min}$. The RT reaction began with a 15 -min incubation at $50{ }^{\circ} \mathrm{C}$, followed by a 5 -min denaturation at $95^{\circ} \mathrm{C}$. The amplification 
procedure was carried out in a Gradient thermal cycler (Biometra, Gottingen, Germany) over 35 cycles, beginning with denaturation at 94 for $30 \mathrm{~s}$, primer annealing at 52 for $30 \mathrm{~s}$, and extension at 72 for $2 \mathrm{~min}$. The last extension was carried out at 72 for $7 \mathrm{~min}$ at the end of the 35th cycle. A PLRV fragment with an anticipated size of ( $548 \mathrm{bp})$ has been amplified [37].

\subsection{Gel Electrophoresis Preparation}

Seven microliters of RT-PCR product were electrophoretically separated on a 1 percent agarose gel in TBE buffer ( 89 mMTris-HCL, pH 8.5) at 120 volts. The size of RT-PCR products was determined using a $100 \mathrm{bp}$ sharp DNA ladder marker (RBC). Gels were stained with $10 \mathrm{~g} / \mathrm{mL}$ ethidium bromide and photographed using a gel-documentation system (Bio-Rad, Hercules, CA, USA, GelDoc XR) [39].

\subsection{Statistical Analysis}

Repeated measures ANOVA were performed for shoots and leaves number. Two-way ANOVA with replication has been applied to test the $p$ value of qRT-PCR results. ${ }^{*} p<0.05$, ${ }^{* *} p<0.01$ and ${ }^{* * *} p<0.001$.

\section{Results}

\subsection{Docking Studies}

Potato leaf roll virus is composed of a pyramidal shaped protein coat divided into three subunits of nearly the same size (A, B and C) with the largest active site (described as the central acidic patch) which is the central core located in between the three subunits. The substrate-binding pocket of leaf roll virus is thought to be this core acidic patch. A molecular docking simulation of glycyrrhizic acid ammonium salt and salicylic acid into the active site of the leaf roll virus was performed. They were stabilized at the core binding site by a variety of electrostatic connections (Figure 1). The order of binding strength was as follows: salicylic acid glycyrrhizic acid ammonium salt.

Both compounds demonstrated excellent binding and great stabilities. We procured many positions with high binding modes and interconnections within the receptor pocket, but we chose the ones with the highest acceptable scores (linked to pose consistency) and RMSD refine values (relevant to a specific pose's connectedness to the initial ligand position within the receptor pocket). Whereas a higher binding score value implies that the tested chemical has a high binding affinity for the target receptor. Furthermore, an RMSD refine value $<2$ shows the proximity of the docked compound pose to its starting position, which corresponds to the drug design program's correctness. The results of interaction energy with the potato leaf roll virus are presented in (Table 2).

Table 2. Receptor interaction with identified glycyrrhizic acid ammonium salt and salicylic acid into the central binding site in the leaf roll viral protein coat.

\begin{tabular}{|c|c|c|c|c|}
\hline Compound & $\begin{array}{c}\text { Score } \\
\text { Kcal/Mole }\end{array}$ & RMSD_Refine & Amino Acid Bond & $\begin{array}{c}\text { Distance } \\
\AA\end{array}$ \\
\hline \multirow{9}{*}{$\begin{array}{l}\text { Glycyrrhizic acid } \\
\text { ammonium salt }\end{array}$} & \multirow{9}{*}{-8.95} & \multirow{9}{*}{2.09} & Asp A177/H-acceptor & 2.76 \\
\hline & & & Asp A177/H-acceptor & 2.86 \\
\hline & & & Cys A139/H-donor & 3.01 \\
\hline & & & Glu A176/H-acceptor & 2.84 \\
\hline & & & His A172/H-donor & 2.86 \\
\hline & & & Trp A171/H-acceptor & 2.44 \\
\hline & & & Lys B140/H-donor & 3.23 \\
\hline & & & Glu C170/H-donor & 2.79 \\
\hline & & & Asn C167/H-donor & 3.17 \\
\hline
\end{tabular}


Table 2. Cont.

\begin{tabular}{|c|c|c|c|c|}
\hline Compound & $\begin{array}{c}\text { Score } \\
\text { Kcal/Mole }\end{array}$ & RMSD_Refine & Amino Acid Bond & $\begin{array}{c}\text { Distance } \\
\AA\end{array}$ \\
\hline \multirow{4}{*}{ Salicylic acid } & \multirow{4}{*}{-3.83} & \multirow{4}{*}{1.04} & Asp 177/H-acceptor & 2.95 \\
\hline & & & Cys 139/H-donor & 3.06 \\
\hline & & & Cys 139/H-donor & 3.07 \\
\hline & & & His $172 /$ pi-H & 4.26 \\
\hline
\end{tabular}

Glycyrrhizic acid ammonium salt

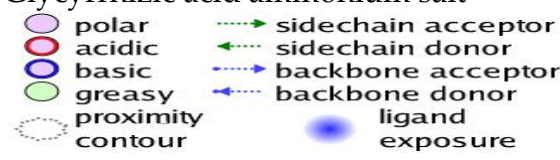

Asn

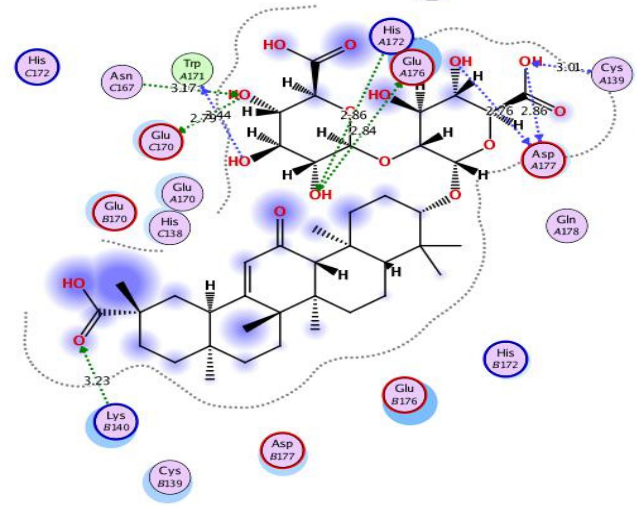

His
$2 \mathrm{D}$

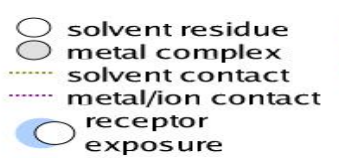

Salicylic acid

으은 arene-arene

을 arene-H

아 arene-cation

exposure

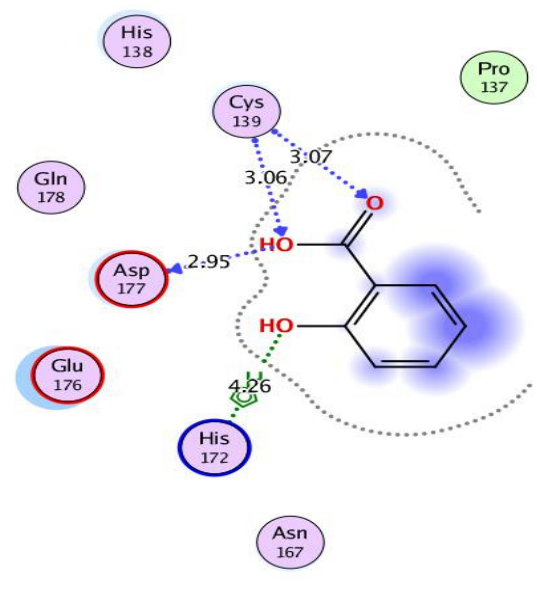

$3 \mathrm{D}$

Glycyrrhizic acid ammonium salt

Salicylic acid

Red dashed lines refer to hydrogen bonds, while the black ones denote hydrophobic interactions
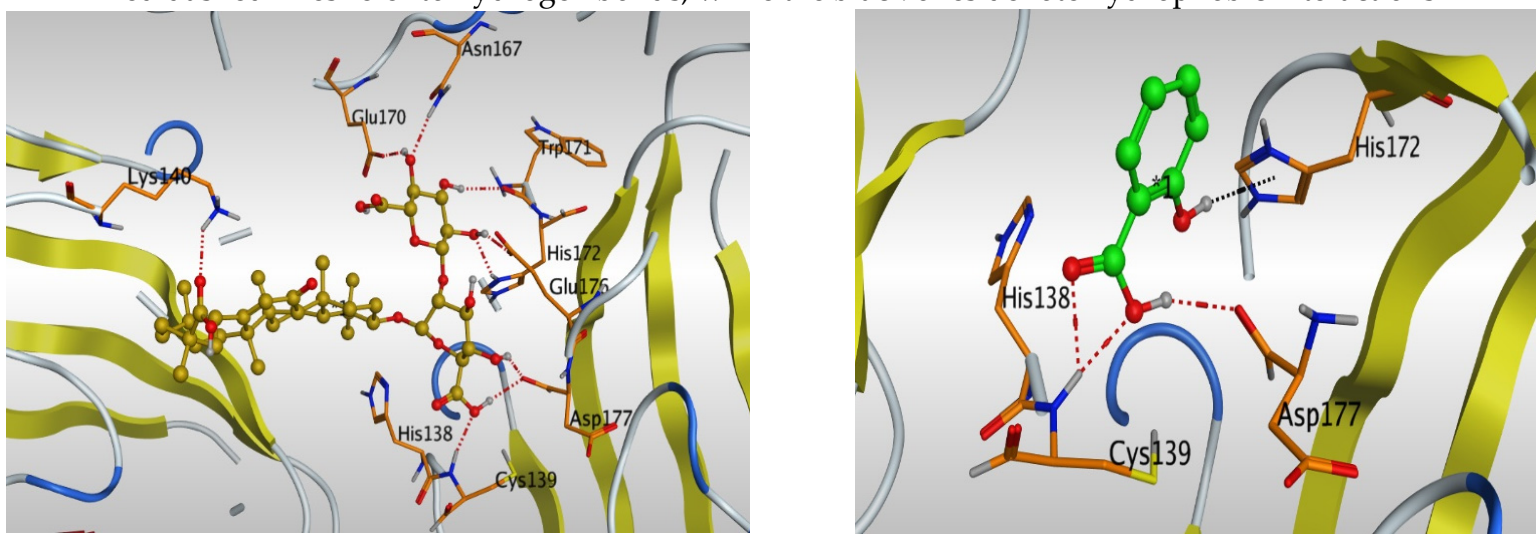

Figure 1. 2D and 3D representation of docking of compounds: glycyrrhizic acid and salicylic acid into the central binding site of leaf roll viral protein coat.

\section{2. $2 D$ and 3D Images of Docked Molecules Showing That}

Glycyrrhizic acid ammonium salt fitted itself in between the three subunits of leaf roll viral protein coat (the central acidic patch) through nine H-bonds formation. Six H-bonds with Asp 177, Cys 139, Glu 176, His 172 and Trp 171 amino acids of subunit A. One H-bond with Lys 140 amino acid of subunit B. Two H-bonds with Glu 170 and Asn 167 amino acids 
of subunit C. Indicating a superior affinity of glycyrrhizic acid against leaf roll virus and an expected higher efficacy as well.

On the other hand, salicylic acid formed three $\mathrm{H}$-bonds and one pi-H bond with the pocket amino acids of subunit C. The three H-bonds with Asp 177 and Cys 139 amino acids, and the pi-H bond with His 172 amino acid. So, a good affinity of salicylic acid to the receptor pocket is confirmed with an expected good activity.

Another way used to clarify the poisoning of both glycyrrhizic acid and salicylic acid inside the receptor pocket of leaf roll viral protein coat, is by showing them in the form of 3D filling compounds inside the viral protein coat (Figure 2). This clarifies the positioning of the tested compounds inside the binding pocket of the target receptor which confirms the great binding affinity and the expected intrinsic activity as well.
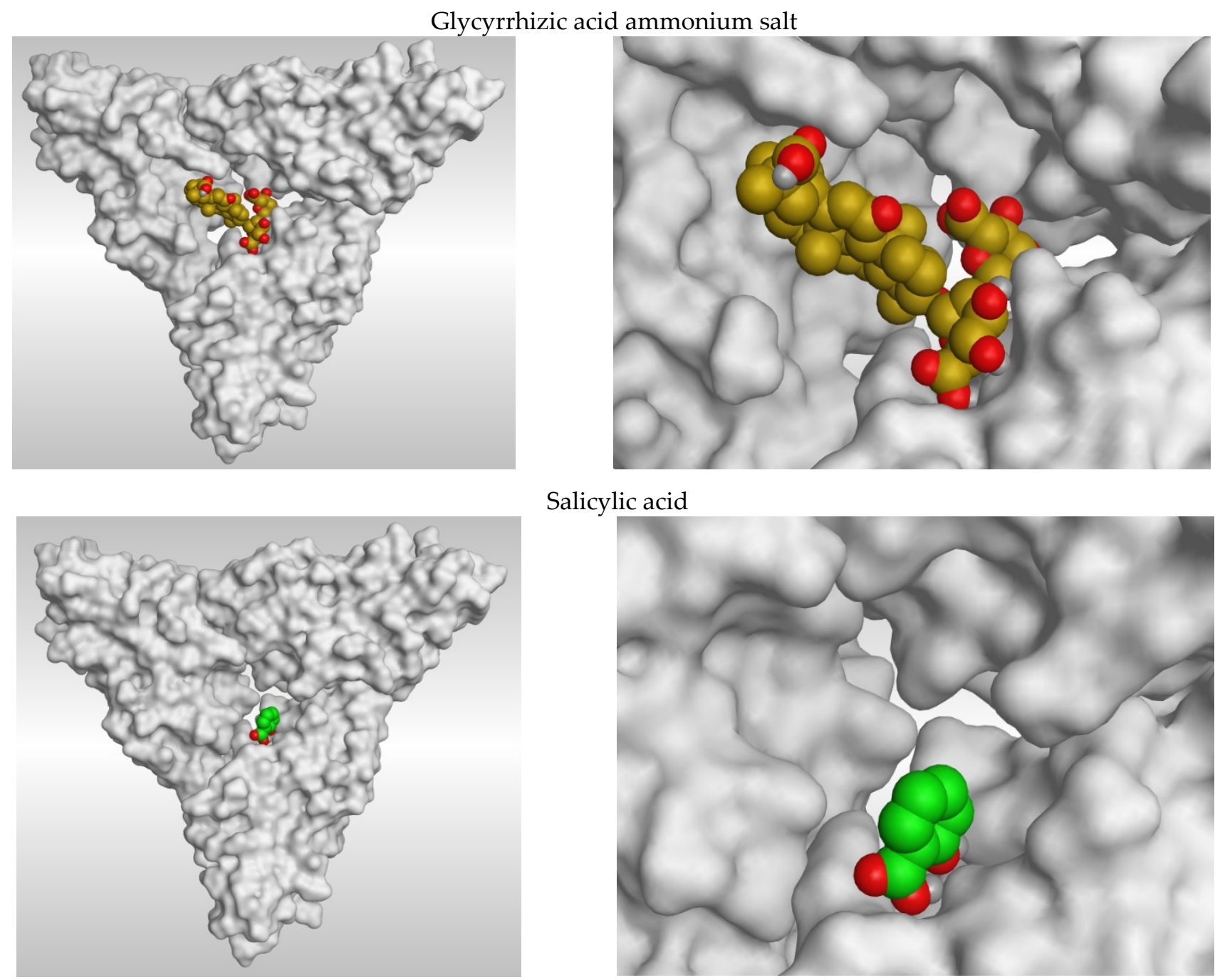

Figure 2. Surface of leaf roll viral protein coat showing the positioning and fitting of tested compounds, glycyrrhizic acid and salicylic acid, respectively.

Finally, to evaluate the electrostatics of our tested compounds inside the central acidic patch of the protein coat, we assigned their electrostatic map (Figure 3). Where the red colors indicate the acidic regions of the receptor pocket, while the blue regions indicate the basic regions of the receptor pocket. This shows the binding of the tested compounds inside the target receptor according to its acidic and basic functional groups. This was added to the manuscript as requested. 

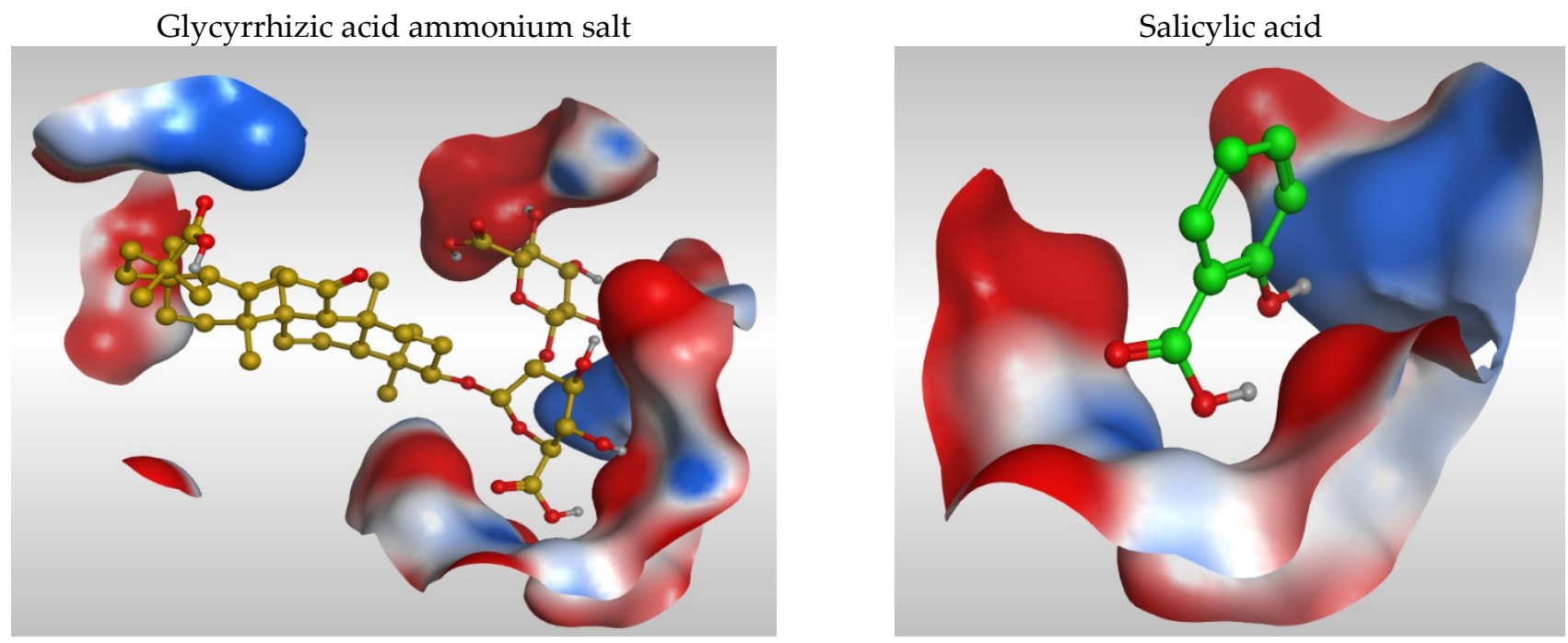

Figure 3. Surface and maps of our tested compounds, glycyrrhizic acid and salicylic acid, respectively, inside the central acidic patch of leaf roll viral protein coat.

\subsection{Dynamic Light Scattering (DLS)}

At room temperature, salicylic acid and glycyrrhizic acid ammonium distribution and size were measured using a dynamic light scattering technique using a Zetasizer Nano ZS (Malvern Instruments, Malvern, UK). $30 \mu \mathrm{L}$ of the nanoparticle was diluted with $3 \mathrm{~mL}$ of water at $25^{\circ} \mathrm{C}$ before to measurement. The mean of the Z-average of three separate batches of nanoparticles was used to calculate particle size. Light scattering in motion (DLS) The size distribution and stability of produced glycyrrhizic acid ammonium salt and salicylic acid nanoparticles were studied using dynamic light scattering. The size distribution was primarily between $5-7 \mathrm{~nm}$ and 20-26.6 nm, respectively, as shown in (Figures 4 and 5). The zeta potential is a key indicator of the stability of colloidal dispersions. So, colloids with high zeta potential (positive) are electrically stabilized (Figures 6 and 7).

\section{Size Distribution by Volume}

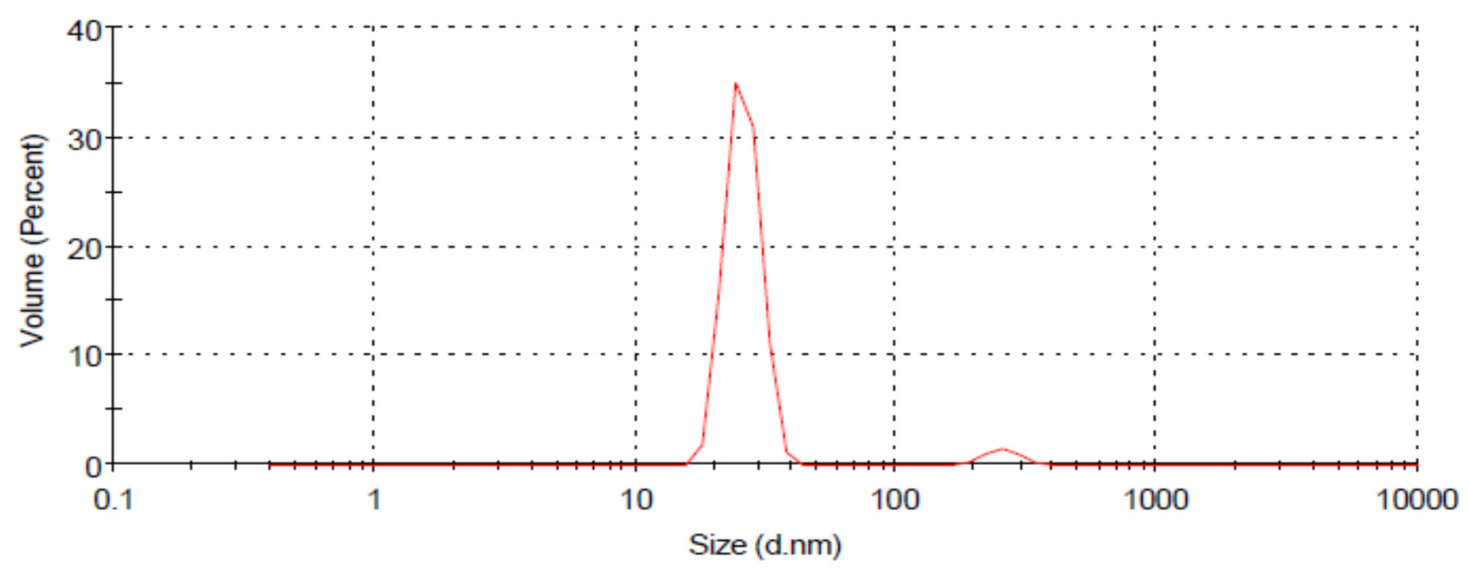

Figure 4. Z average size of SA NPs, $26.6 \mathrm{~nm}$. 
Size Distribution by Volume

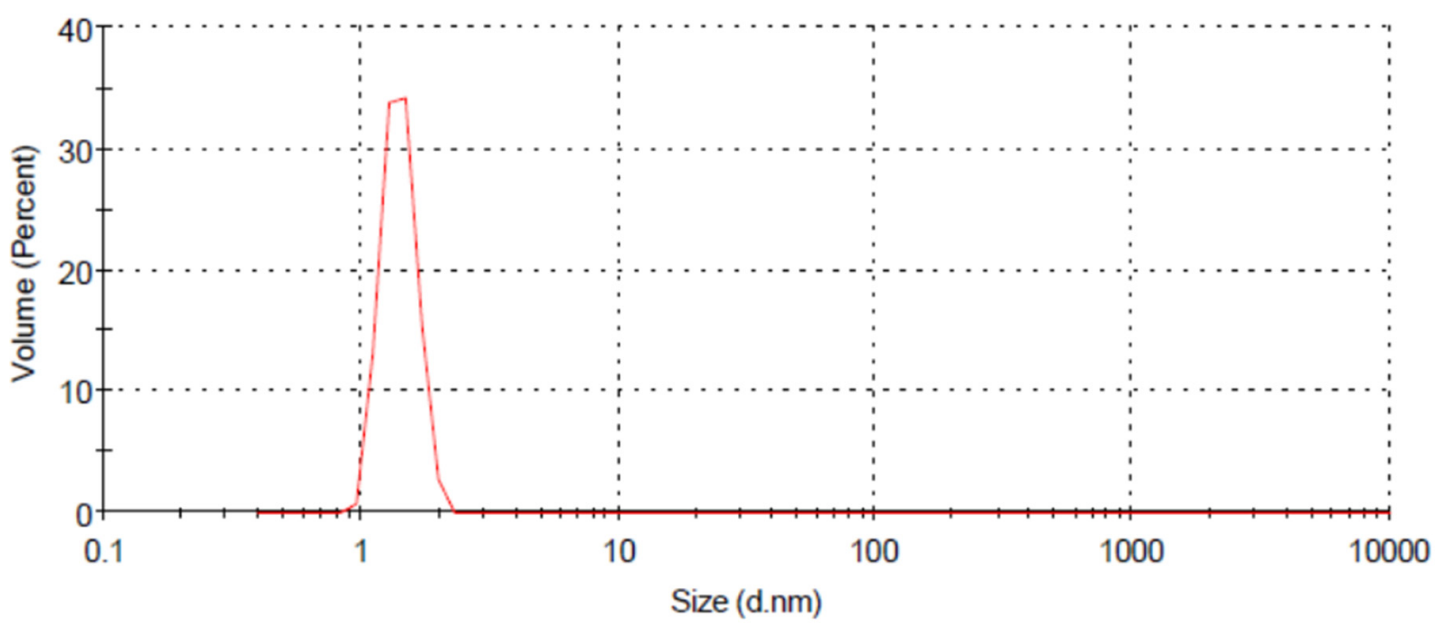

Figure 5. Z average size of Glycyrrhizic acid ammonium salt nanoparticles.

Zeta Potential Distribution

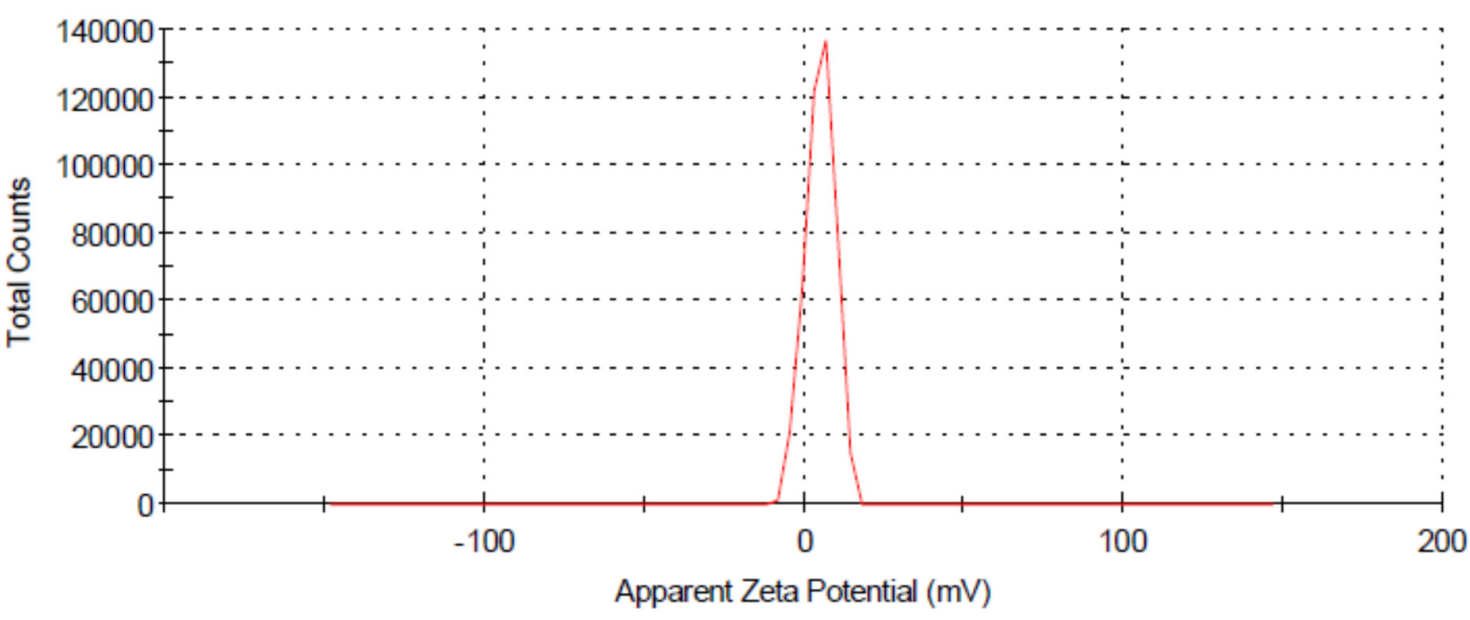

Figure 6. Zeta potential for salicylic acid nanoparticles.

Zeta Potential Distribution

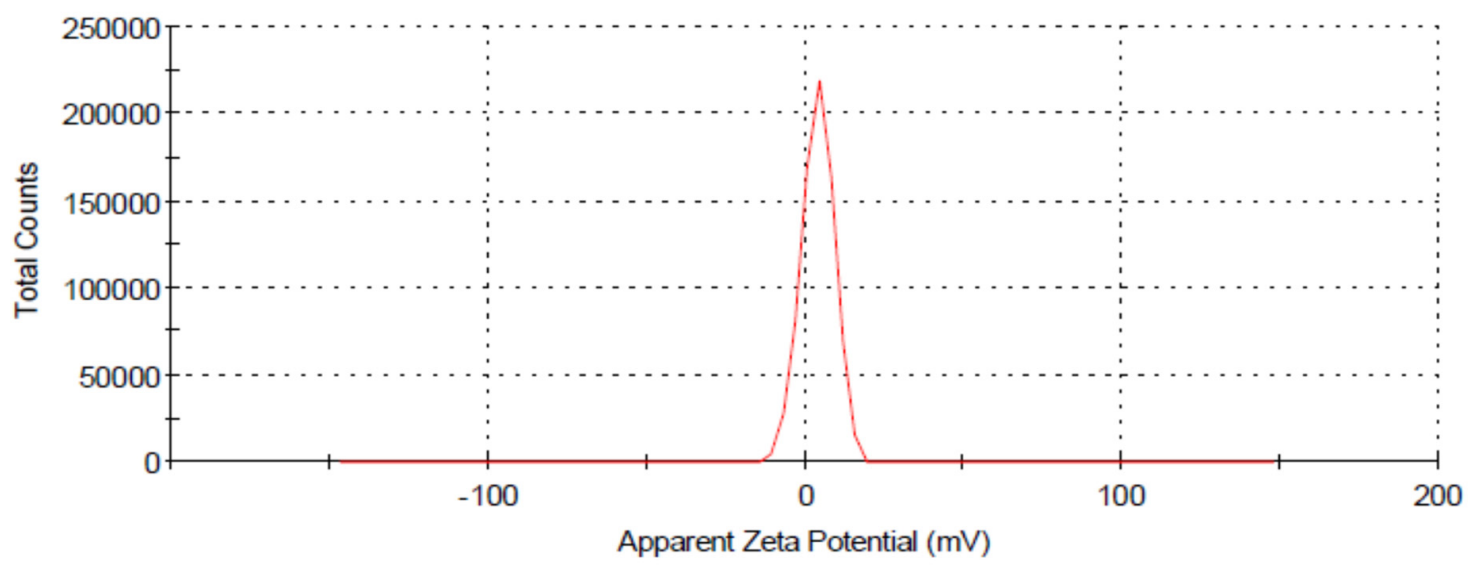

Figure 7. Zeta potential for of Glycyrrhizic acid ammonium salt nanoparticles. 
3.4. Effect of Salicylic Acid and Glycyrrhizic Acid Ammonium Salt Nanoparticles on the Shoots and Leaves Number Compared to Positive Control

Figure 4 showed that the average number of shoots of infected tissue cultured potato plantlets was (7.5) in response to $2.5 \mathrm{mM}$ SA NPs, while the other treatments $1.25 \mathrm{mM} \mathrm{SA}$ NPs, $0.15 \mathrm{mM}$ GA NPs and $0.30 \mathrm{mM}$ recorded the same average number (5.5) compared to (2.75) in the control. On the other hand, the average number of leaves of infected tissue cultured potato plantlets in response to $2.5 \mathrm{mM}$ SA NPs recorded the highest number (30.75), while the other treatments with $1.25 \mathrm{mM}$ SA NPs, $0.30 \mathrm{mM}$ GA NPs and $0.15 \mathrm{mM}$ GA NPs recorded (24.25, 24.25 and 23.75), respectively, compared to (15.3) in the control, one week after different treatments (Figures 8 and 9).

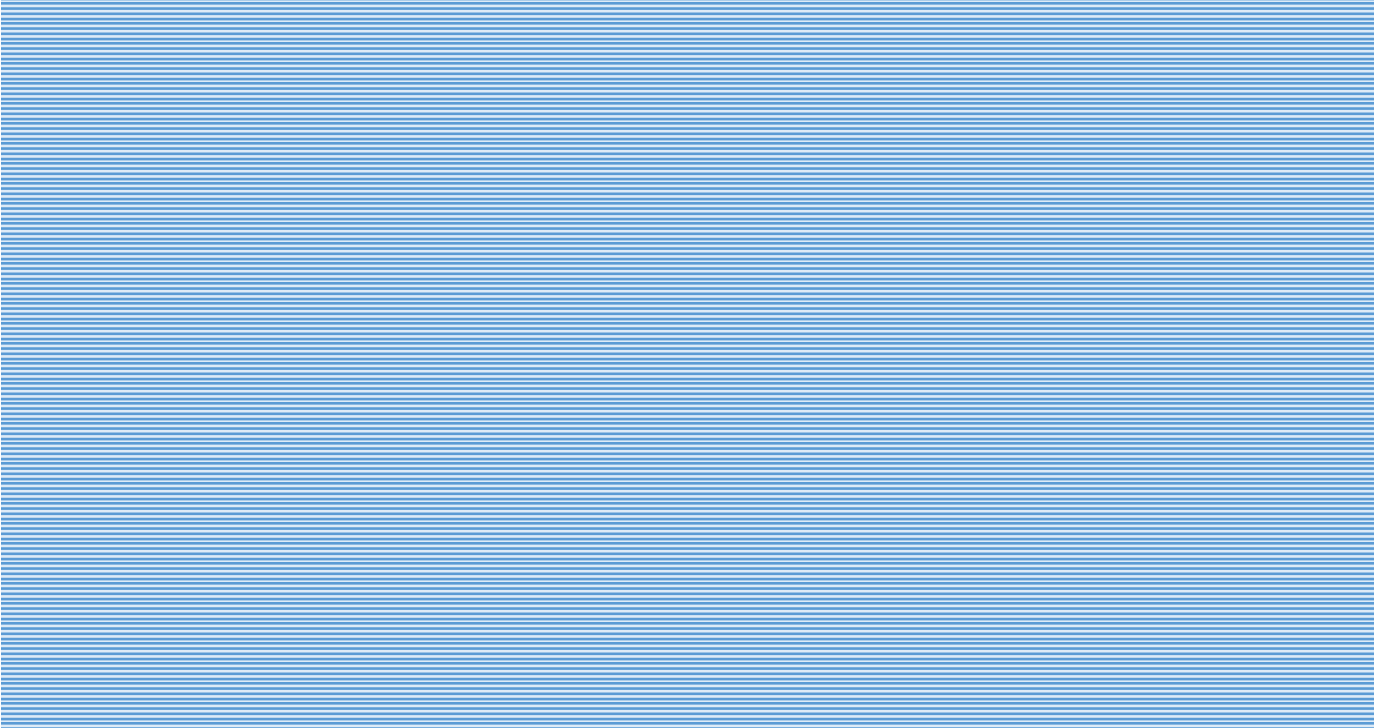

Figure 8. The average number of shoots in infected tissue cultured potato plantlets Solanum tuberosum L. selena with PLRV in response to salicylic acid ( 1.25 and $2.5 \mathrm{mM})$ and Glycyrrhizic Acid ammonium salt ( 0.15 and 0.30 mM) nanoparticles compared to positive control after one week. Two-way ANOVA was used to analyze the data. ${ }^{* * *} p<0.001$ show significant variations in the number of shoots.

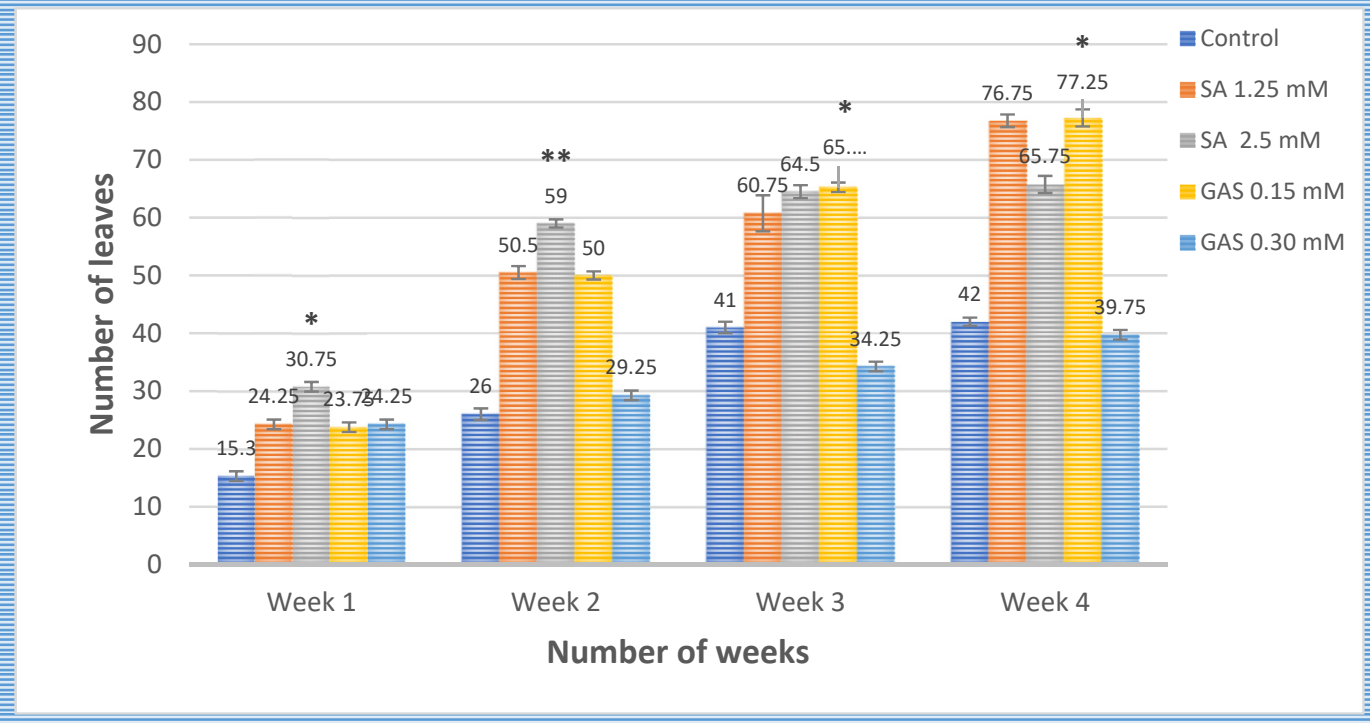

Figure 9. The average number of leaves in infected tissue cultured potato plantlets Solanum tuberosum L. selena with PLRV in response to salicylic acid ( 1.25 and $2.5 \mathrm{mM})$ and Glycyrrhizic Acid ammonium salt (0.15 and 0.30 mM) nanoparticles compared to positive control after two weeks. Two-way ANOVA was used to analyze the data. ${ }^{*} p<0.05,{ }^{* *} p<0.01$ show significant variations in the number of shoots. 
The average number of shoots in infected tissue cultured potato plantlets was (10.5, $12.25,10,6.5$ branches $)$ in response to SA NPs $(1.25$ and $2.50 \mathrm{mM})$ and GA NPs $(0.15$ and $0.30 \mathrm{mM})$, respectively, compared to (5.75) in the control, two weeks after treatments (Figure 6). However, treated potato plantlets with (2.50 mM SA NPs) recorded the highest average number of leaves (59) followed by (50.5, 50 and 29.24 leaves) in response to $1.25 \mathrm{mM}$ SA NPs, $0.15 \mathrm{mM}$ GA NPs and $0.30 \mathrm{mM}$ GA NPs, respectively, compared to (26) leaves in the control, two weeks after treatments (Figures 8 and 9).

Unexpectedly, the average number of leaves in infected tissue cultured potato plantlets recorded the highest number (65.25) in response to $0.15 \mathrm{mM} \mathrm{GA} \mathrm{NPs} \mathrm{compared} \mathrm{to} \mathrm{(64.5} \mathrm{and}$ 60.75 ) in response to 2.5 and $1.25 \mathrm{mM} \mathrm{SA} \mathrm{NPs,} \mathrm{respectively.} \mathrm{While,} \mathrm{treated} \mathrm{potato} \mathrm{plantlets}$ with $0.30 \mathrm{mM}$ GA NPs recorded the lowest average number of leaves (34.25) compared to (41) in the control, three weeks after treatments (Figure 5). The average number of shoots recorded $(15,14.25$ and 13.5$)$ in response to $0.15 \mathrm{mM} \mathrm{GA} \mathrm{NPs}, 1.25 \mathrm{mM}$ and $2.5 \mathrm{mM}$ SA NPs, respectively, while $0.30 \mathrm{mM}$ GA NPs scored the lowest average number of shoots (7) compared to (7.5) in the control, three weeks after treatments (Figures 8 and 9).

All At Once, the average number of leaves in infected tissue cultured potato plantlets recorded the highest number (77.25) in response to $0.15 \mathrm{mM}$ GA NPs compared to (76.75 and 65.75) in response to 1.25 and $2.5 \mathrm{mM}$ SA NPs, respectively. While, treated potato plantlets with $0.30 \mathrm{mM}$ GA NPs recorded the lowest average number of leaves (39.75) compared to (42) in the control, three weeks after treatments (Figure 7). The average number of shoots recorded $(16,15.75$ and 14.25) in response to1.25 mM SA NPs, $0.15 \mathrm{mM}$ GA NPs and $2.5 \mathrm{mM}$ SA NPs, respectively, while $0.30 \mathrm{mM}$ GA NPs scored the lowest average number of shoots (8.25) compared to (8) in the control, three weeks after treatments (Figures 8 and 9).

Detecting the presence or absence of PLRV using PCR primers revealed that the treatments of infected tissue cultured potato plantlets with $0.30 \mathrm{mM}$ and $0.15 \mathrm{mM}$ GA NPs showed very faint bands in response to treatment; however, SA NPs at the concentrations of 1.25 and $2.5 \mathrm{mM}$ SA NPs showed faint bands of PLRV. While potato plants positive control (Infected with PLRV) ( 548 bp) and PV+, Kit positive control PLRV showed very strong bands (Figure 10).

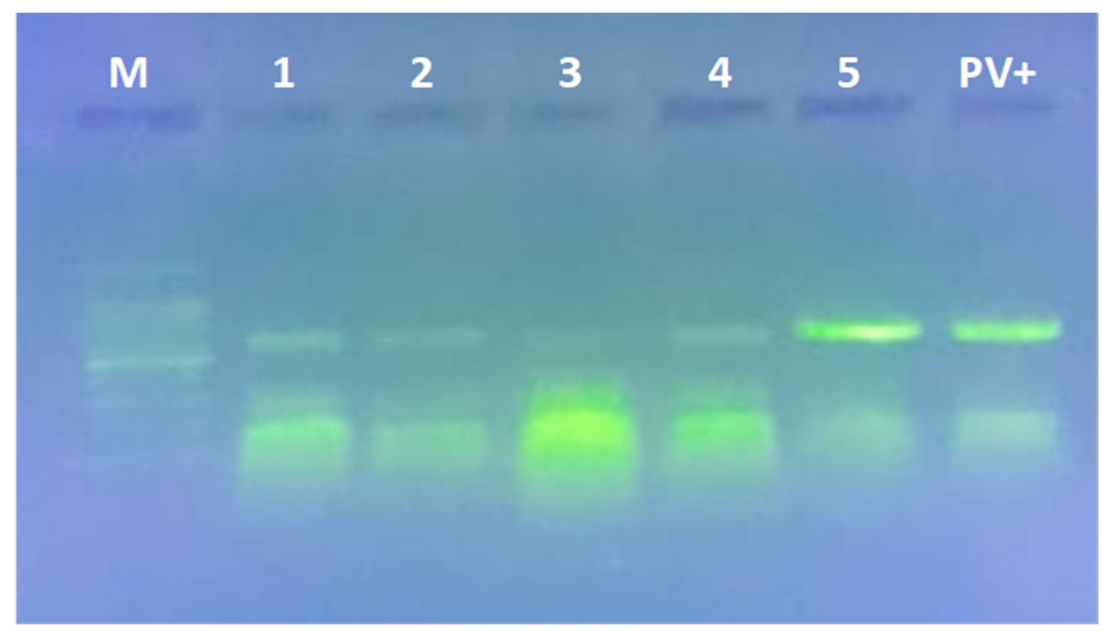

Figure 10. Gel electrophoresis analysis for potato (selana) tested for PLRV using RT-PCR utilizing specific PCR primers. Lane M 1 Kb DNA Marker. L1, infected potato plants with PLRV treated with Salicylic acid (1.25 mM), Lane 2, infected potato plants with PLRV treated with Salicylic acid (2.5 mM), Lane 3, infected potato plants with PLRV treated with glycyrrhizic acid ammonium salt $(0.30 \mathrm{mM})$, Lane 4 , infected potato plants with PLRV treated with glycyrrhizic acid ammonium salt $(0.15 \mathrm{mM})$. Lane 5, Potato plants positive control infected with PLRV ( 548 bp) Lane PV+, Kit positive control PLRV. 


\subsection{Gene Expression}

The expression level of Kinase 3 gene increased significantly due to the two used concentrations of GAS NPs. While the expression of callose gene was upregulated significantly in response to treatment of infected plant with (GAS NPs) with concentration $(0.30 \mathrm{mM})$. Regards to (SA NPs) treatment, these treatments caused upregulation significance only of callose gene at $(2.5 \mathrm{mM})$ treatment. The expression level of Kinase Kinase 3 gene reached to the highest level 4.9 folds in response to $0.30 \mathrm{mM}$ GAS NPs compared to 2.7, 2.6 and 1.08 folds in response to $0.15 \mathrm{mM}$ GAS NPs, $2.5 \mathrm{mM}$ SA NPs and $1.25 \mathrm{mM} \mathrm{SA}$ NPs, respectively. Alternatively, the expression level of Callose synthase 2 scored the highest number of folds (4.4) in response to $2.5 \mathrm{mM}$ SA NPs compared to 2.8, 2.4 and 1.05 folds in response to $0.30 \mathrm{mM}$ GAS NPs, $0.15 \mathrm{mM}$ GAS NPs and $1.25 \mathrm{mM}$ SA NPs, respectively. Additionally, Actin reference gene expressed to (1) fold in response to different treatments (Figure 11).

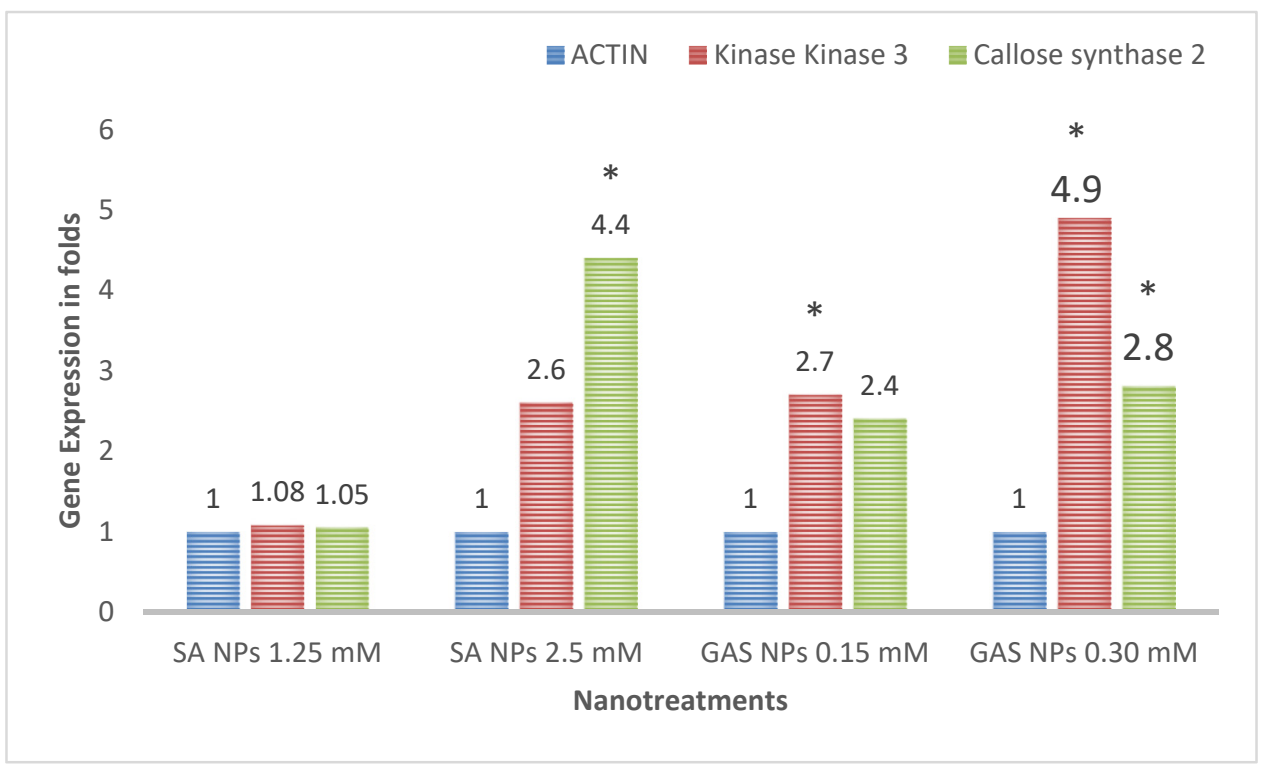

Figure 11. Expression level of Kinase Kinase 3, Callose synthase 2 and Actin reference genes in response to salicylic acid and glycyrrhizic acid ammonium salt nanoparticles. Statistically significant indicated by * $p$ value $<0.05$.

\section{Discussion}

Potato leafroll virus (PLRV) is regarded as one of the most significant and devastating potato pathogenic viral infections. Potato Leafroll Virus (PLRV) initiates serious harm and great yield losses above 50\% [40]. The best current management strategies to treat viral infected potato plants with PLRV is eliminating infected plants using safe quarantine protocol. Alternatively, shoot tip meristem technique may produce potato plants free viruses. Currently, there is no successful management strategies to cure the infected plants with PLRV. Tissue culture technique may be applied effectively to reduce or decline the presence of PLRV using chemotherapy and thermotherapy protocols along with the physical characteristics of the virus. Our research was aiming to study In-Silico the effect of Glycyrrhizic Acid ammonium salt (GAS) and Salicylic acid on the coat protein of PLRV. In addition, studying in-vitro the effect of Glycyrrhizic Acid ammonium salt (GAS) and Salicylic acid nanoparticles nanoparticles to control, decline or reduce the presence of PLRV in potato plants Solanum tuberosum L. selena.

In-Silico studies showed that glycyrrhizic acid ammonium salt and salicylic acid showed good bindings with high stabilities. Many poses were obtained with better binding modes and interactions inside the receptor pocket, but selected ones having the most acceptable scores (related to the stability of the pose) and RMSD_refine values (Table 2). Glycyrrhizic acid ammonium salt fitted itself in between the three subunits of leaf roll viral protein coat (the central acidic patch) through nine H-bonds formation. Six H-bonds with 
Asp 177, Cys 139, Glu 176, His 172 and Trp 171 amino acids of subunit A. One H-bond with Lys 140 amino acid of subunit B. Two H-bonds with Glu 170 and Asn 167 amino acids of subunit $C$. Indicating a superior affinity of glycyrrhizic acid ammonium salt against leaf roll virus and an expected higher efficacy as well. On the other hand, salicylic acid formed three $\mathrm{H}$-bonds and one pi-H bond with the pocket amino acids of subunit $\mathrm{C}$. The three H-bonds with Asp 177 and Cys 139 amino acids, and the pi-H bond with His 172 amino acid. So, a good affinity of salicylic acid to the receptor pocket is confirmed with an expected good activity. Accordingly, Glycyrrhizic acid ammonium salt showed more activities than salicylic acid against potato leafroll virus (PLRV (Table 2, Figures 1-3). Glycyrrhizic Acid ammonium salt (GAS NPs) and salicylic acid (SA NPs) were applied at concentrations $0.15,0.30,1.25$ and $2.5 \mathrm{mM}$, respectively, in the MS medium to study the impact of those nanomaterials on infected potato plantlets with PLRV. Different applied nanomaterials exist in all plants at different concentrations and could be enhanced or declined according to the initiation of specific pathways and assembly of certain secondary metabolites. Application of nanomaterials may positively or negatively affect at certain concentrations on the presence and absence of PLRV, growth rate and immunity of the plants. Glycyrrhizic Acid ammonium salt (GAS NPs) at high concentration $0.30 \mathrm{mM}$ had no great impact on the growth of potato plantlets but suppressed the presence of PLRV virus. Meanwhile, Glycyrrhizic Acid ammonium salt (GAS NPs) at low concentration $0.15 \mathrm{mM}$ had great impact on the potato plantlet growth and suppressed PLRV. Salicylic acid nanoparticles (SA NPs) had positive impact on the growth of potato plantlets and the suppression of PLRV, but GAS NPs had more great impact on reducing the presence of PLRV (Figures 8-11).

The treatment of diseased tissue cultured potato plantlets with Glycyrrhizic Acid ammonium salt (GAS NPs) and salicylic acid nanoparticles (SA NPs) stimulated many signal transduction pathways and the bioactive compounds terpenoids and glycyrrhizin, which elevated the resistant levels of potato platelets in response to PLRV (Figure 12). The elevation of kinase kinase 3 and callose synthase genes may be due to the stimulation of many signaling channels, including the oxidative inducible gene (oxi1 gene), ROS and calcium signaling cascades.

Reactive oxygen species (ROS) are the initial line of defense that is spontaneously produced within a few seconds in response to biotic and abiotic stressors; they may also function as protectants against various stresses and signal activators [41].

ROS induction is necessary to completely activate Mitogen-activated protein kinases (MAPKs) genes, which are regarded as well-studied signaling families in higher plants. Furthermore, MAPKs govern a wide range of vital and critical cellular functions such as cell division, stress responses, metabolism and many developmental processes that are controlled by hormones and physiologically active substances.

Oxidative signal Inducible1 (Oxi1) is a necessary serine/threonine kinase, a member of the AGC protein kinase family and a protein kinase that involves ROS accumulation to enhance plant tolerance to various inducements and oxidative burst-mediated signaling in plant roots [42]. MAPK genes are also essential critical players in calcium signaling pathways, which govern several processes such as stomata opening and closure and callose deposition [43]. In response to stimulation, MAPK cascades also govern leaf growth and root elongation.

Our study found that using GAS NPs and SA NPs stimulated MAPK cascades and enhanced plant growth to some extent by increasing photosynthetic pathways growth hormones (Figure 12). In addition, the activation of MAPK cascades resulted in an upsurge in trichrome glandular density, which had a favorable effect on phytohormone levels.

Increasing phytohoromone levels activates the plastidic MEP (Methyl Erythritol Phosphate) and cytosolic MVA (mevalonate) pathways. Both the MEP and MVA pathways stimulate IPP (Isopentenyl Pyrophosphate) and DMAPP (Dimethylallyl Pyrophosphate), which are essential in the initiation of the Terpene synthesis pathway, which results in the production of terpenoids such as Sabinene, phyllandrene and other essential oils that 
have a positive effect on resistance levels to various stimuli. Due to the increased root length, leaf area and photosynthesis pathways, nutrient materials and water absorption enhanced. Nitrogen absorption, which is regarded as a key core component of amino acids and enzymes, might benefit terpenoid biosynthesis.

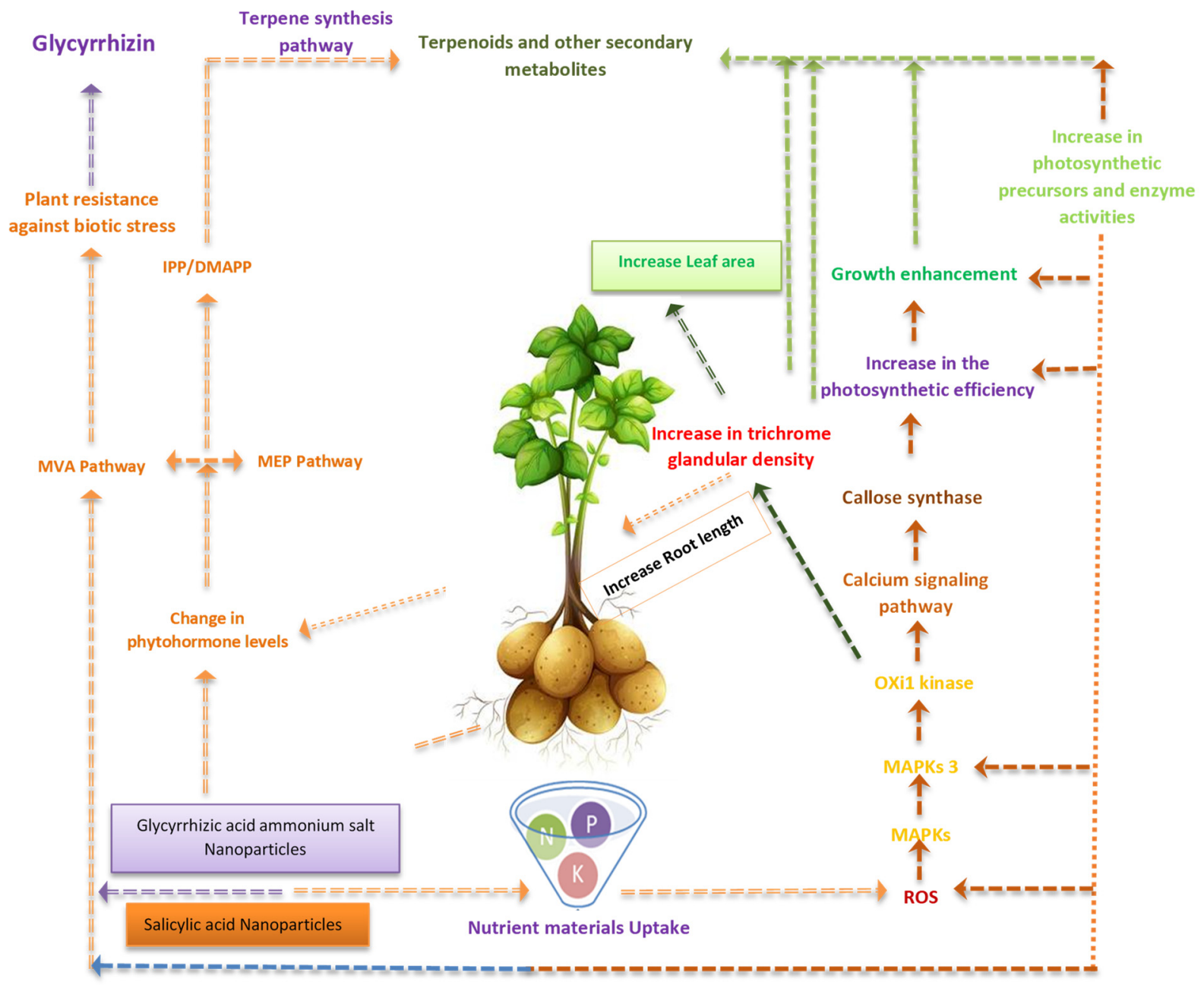

Figure 12. Schematic diagram for different physiological pathways in infected tissue cultured Solanum tuberosum L. selena with PLRV in response to Glycyrrhizic acid ammonium salt and salicylic acid nanoparticles.

\section{Conclusions}

The molecular modelling of the selected compounds, glycyrrhizic acid ammonium salt and salicylic acid, led to the approval of their high potential activity as leaf roll virus inhibitors. This will encourage the evaluation of these compounds as anti-leaf roll, particularly glycyrrhizic acid ammonium salt, which demonstrated the highest binding score and the best rmsd refine value with a very good binding mode and perfect interactions with amino acids of the three subunits (A, B and C) forming the leaf roll virus's protein coat.

Glycyrrhizic acid ammonium salt and salicylic acid nanoparticles could be perfect solution to produce potato plant free virus in-vitro. Certain nanomaterials could suppress the PLRV virus via the induction of plant defense mechanism or suppress the reproduction stages of PLRV. Nanoparticles induced plant defense mechanism and secondary metabolites which successfully suppressed PLRV and enhanced plant full defense system. Nanomaterials could be applied successfully in-vitro and in-vivo to manage plant viruses. Further research studies required to investigate the mode of action of nanoparticles against plant viruses. In addition, further studies required to discover the management strategies using nanoparticles. 
Author Contributions: Conceptualization, T.S. and N.S.A.; methodology, T.S. and N.S.A.; software, T.S. and A.A.A.-K.; validation, S.M.A. and M.A.A.; formal analysis, T.S., N.S.A. and A.A.A.-K.; investigation, T.S. and N.S.A.; resources, T.S., N.S.A., S.M.A. and M.A.A.; data curation, T.S., N.S.A., M.O.G., S.M.A. and M.A.A.; writing—original draft preparation, T.S., N.S.A.; writing-review and editing, T.S., N.S.A. and A.A.A.-K.; visualization, T.S., N.S.A., A.A.A.-K., M.O.G., S.M.A. and M.A.A.; supervision, T.S. and N.S.A.; project administration, T.S., N.S.A.; funding acquisition, S.M.A., M.A.A. and M.O.G. All authors have read and agreed to the published version of the manuscript.

Funding: This research received no external funding.

Institutional Review Board Statement: Not applicable.

Informed Consent Statement: Not applicable.

Conflicts of Interest: The authors declare no conflict of interest.

\section{References}

1. Kreuze, J.F.; Souza-Dias, J.A.C.; Jeevalatha, A.; Figueira, A.R.; Valkonen, J.P.T.; Jones, R.A.C. Viral Diseases in Potato. In The Potato Crop; Campos, H., Ortiz, O., Eds.; Springer: Cham, Switzerland, 2020. [CrossRef]

2. Chatzivassiliou, E.K.; Moschos, E.; Gazi, S.; Koutretsis, P.; Tsoukaki, M. Infection of Potato Crops and Seeds with Potato Virus y and Potato Leafroll Virus in Greece. J. Plant. Pathol. 2008, 90, 253-261.

3. IHIDMA. Pharmacopoeia; Indian Herbal Indian Drug Manufacturers Association: Mumbai, India, 2002.

4. Pompei, R.; Flore, O.; Marccialis, M.A.; Pani, A.; Loddo, B. Glycyrrhizic acid inhibits virus growth and inactivates virus particles. Nature 1979, 281, 689-690. [CrossRef]

5. Ates, D.A.; Turgay, O. Antimicrobial activities of various medicinal and commercial plant extracts. Turk. J. Biol. 2003, 27, 157-162.

6. Alonso, J. Tratado de Fitofármacos y Nutracéuticos, 1st ed.; Editorial Corpus Libros: Rosario, Argentina, 2004.

7. Fu, Y.; Chen, J.; Li, Y.J.; Zheng, Y.F.; Li, P. Antioxidant and anti-inflammatory activities of six flavonoids separated from licorice. Food Chem. 2013, 141, 1063-1071. [CrossRef]

8. Amirghofran, Z. Medicinal plants as immunosuppressive agents in traditional Iranian medicine. Iran. J. Immunol. 2010, 7, 65. [PubMed]

9. Krausse, R.; Bielenberg, J.; Blaschek, W.; Ullmann, U. In Vitro anti- Helicobacter pylori activity of Extractum liquiritiae, glycyrrhizin and its metabolites. J. Antimicrob. Chemother. 2004, 54, 243-246. [CrossRef]

10. Li, Y.; Sun, F.; Jing, Z.; Wang, X.; Hua, X.; Wan, L. Glycyrrhizic acid exerts anti-inflammatory effect to improve cerebral vasospasm secondary to subarachnoid hemorrhage in a rat model. Neurol. Res. 2017, 39, 727-732. [CrossRef] [PubMed]

11. Han, S.; Sun, L.; He, F.; Che, H. Anti-allergic activity of glycyrrhizic acid on IgE-mediated allergic reaction by regulation of allergy-related immune cells. Sci. Rep. 2017, 7, 7222. [CrossRef] [PubMed]

12. Kim, Y.W.; Kang, H.E.; Lee, M.G.; Hwang, S.J.; Kim, S.C.; Lee, C.H.; Kim, S.G. Liquiritigenin, a flavonoid aglycone from licorice, has a choleretic effect and the ability to induce hepatic transporters and phase-II enzymes. Am. J. Physiol. Gastrointest. Liver Physiol. 2009, 296, G372-G381. [CrossRef]

13. Ahmad, P.; Nabi, G.; Ashraf, M. Cadmium-induced oxidative damage in mustard [Brassica juncea (L.) Czern. \& Coss.] plants can be alleviated by salicylic acid. S. Afr. J. Bot. 2011, 77, 36-44.

14. Nazar, R.; Iqbal, N.; Syeed, S.; Khan, N.A. Salicylic acid alleviates decreases in photosynthesis under salt stress by enhancing nitrogen and sulfur assimilation and antioxidant metabolism deferentially in two mungbean cultivars. J. Plant. Physiol. 2011, 168, 807-815. [CrossRef] [PubMed]

15. Khan, M.I.R.; Fatma, M.; Per, T.S.; Anjum, N.A.; Khan, N.A. Salicylic acid-induced abiotic stress tolerance and underlying mechanisms in plants. Front. Plant. Sci. 2015, 6, 462. [CrossRef] [PubMed]

16. Ali, E.; Maodzeka, A.; Hussain, N.; Shamsi, I.H.; Jiang, L. The alleviation of cadmium toxicity in oilseed rape (Brassica napus) by the application of salicylic acid. Plant. Growth Regul. 2014, 75, 641-655. [CrossRef]

17. Khan, M.I.R.; Asgher, M.; Khan, N.A. Alleviation of salt-induced photosynthesis and growth inhibition by salicylic acid involves glycinebetaine and ethylene in mungbean (Vigna radiata L.). Plant. Physiol. Biochem. 2014, 80, 67-74. [CrossRef] [PubMed]

18. Shoala, T. Positive Impacts of Nanoparticles in Plant Resistance against Different Stimuli. In Nanobiotechnology Applications in Plant Protection, 1st ed.; Abd-Elsalam, K.A., Prasad, R., Eds.; Springer International Publishing: Berlin/Heidelberg, Germany, 2018; pp. 267-279.

19. Richmond, T.A.; Somerville, C.R. The cellulose synthase superfamily. Plant. Physiol. 2020, 124, 495-498. [CrossRef] [PubMed]

20. Xie, B.; Hong, Z. Unplugging the callose plug from sieve pores. Plant. Signal. Behav. 2011, 6, 491-493. [CrossRef]

21. Barratt, D.H.P.; Kölling, K.; Graf, A.; Pike, M.; Calder, G.; Findlay, K.; Zeeman, S.; Smith, A. Callose synthase GSL7 is necessary for normal phloem transport and inflorescence growth in Arabidopsis. Plant. Physiol. 2011, 155, 328-341. [CrossRef]

22. Dong, X.; Hong, Z.; Chatterjee, J.; Kim, S.; Verma, D.P.S. Expression of callose synthase genes and its connection with Npr1 signaling pathway during pathogen infection. Planta 2008, 229, 87-98. [CrossRef]

23. Cui, W.; Lee, J.Y. Arabidopsis callose synthases CalS1/8 regulate plasmodesmal permeability during stress. Nat. Plants 2016, 2, 16034. [CrossRef] 
24. Meng, X.; Zhang, S. MAPK cascades in plant disease resistance signaling. Annu. Rev. Phytopathol. 2013, 51, 245-266. [CrossRef]

25. Mayo, M.A.; D'Arcy, C.J. Family Luteoviridae: A reclassification of luteoviruses. In The Luteoviridae; Smith, H.G., Barker, H., Eds.; CABI Publishing: Wallingford, UK, 1999; pp. 15-22.

26. Miller, W.A.; Dinesh-Kumar, S.P.; Paul, C.P. Luteovirus gene expression. Crit. Rev. Plant. Sci. 1995, 14, 179-211. [CrossRef]

27. Pfeffer, S.; Dunoyer, P.; Heim, F.; Richards, K.E.; Jonard, G.; Ziegler-Graff, V. P0 of beet western yellows virus is a suppressor of posttranscriptional gene silencing. J. Virol. 2002, 76, 6815-6824. [CrossRef]

28. Ashoub, A.; Rohde, W.; Prufer, D. In planta transcription of a second subgenomic RNA increases the complexity of the subgroup 2 luteovirus genome. Nucleic Acids Res. 1998, 26, 420-426. [CrossRef] [PubMed]

29. Massalski, P.R.; Harrison, B.D. Properties of Monoclonal Antibodies to Potato Leafroll Luteovirus and Their Use to Distinguish Virus Isolates Differing in Aphid Transmissibility. J. Gen. Virol. 1987, 68, 1813-1821. [CrossRef]

30. Syller, J. Potato leafroll virus (PLRV): Its transmission and control. Integr. Pest. Manag. Rev. 1996, 1, 217-227. [CrossRef]

31. Khattab, M.; Al-Karmalawy, A.A. Revisiting Activity of Some Nocodazole Analogues as a Potential Anticancer Drugs Using Molecular Docking and DFT Calculations. Front. Chem. 2021, 9, 628398. [CrossRef] [PubMed]

32. Danci, O.; Baciu, A.; Danci, M. Potato (Solanum tuberosum L.) regeneration using the technique of meristem tip culture. J. Biotechnol. Hortic. For. 2011, 15, 175-178.

33. Murashige, T.; Skoog, F. A revised medium for rapid growth and bioassays with tobacco tissue cultures. Physiol. Plant. 1962, 15, 473-479. [CrossRef]

34. Danci, O.; Erdei, L.; Vidacs, L.; Danci, M.; Baciu, A.; David, I.; Berbentea, F. Influence of ribavirin on potato plants regeneration and virus eradication. J. Hortic. For. Biotechnol. 2009, 13, 421-425.

35. Abdel-Rahman, F.A.; Rashid, I.A.; Shoala, T. Nanoactivities of natural nanomaterials rosmarinic acid, glycyrrhizic acid and glycyrrhizic acid ammonium salt against tomato phytopathogenic fungi Alternaria alternata and Penicillium digitatum. J. Plant. Prot. Res. 2020, 60, 150-160.

36. Abdel-Rahman, F.A.; Khafagi, E.Y.; Soliman, M.S.; Shoala, T.; Ahmed, Y. Preharvest application of salicylic acid induces some resistant genes of sweet pepper against black mold disease. Eur. J. Plant. Pathol. 2021, 159, 755-768. [CrossRef]

37. Shoala, T.; Eid, K.; EL-Fiki, I. Impact of Chemotherapy and Thermotherapy Treatments on the Presence of Potato Viruses PVY, PVX and PLRV in Tissue-Cultured Shoot Tip Meristem. J. Plant. Prot. Pathol. 2019, 10, 581-585. [CrossRef]

38. Schmittgen, T.D.; Livak, K.J. Analyzing real-time PCR data by the comparative C(T) method. Nat. Protoc. 2008, 3, 1101-1108. [CrossRef] [PubMed]

39. Sambrook, J.; Fritschi, E.F.; Maniatis, T. Molecular Cloning: A Laboratory Manual; Cold Spring Harbor Laboratory Press: New York, NY, USA, 1989.

40. Wales, S.; Platt, H.W.; Cattlin, N. Diseases, Pests and Disorders of Potatoes: A Colour Handbook, 1st ed.; Manson Publishing Ltd.: London, UK, 2008; pp. 75-76.

41. Hasanuzzaman, M.; Bhuyan, M.H.M.; Faisal, Z.; Ali, R.; Sayed, M.M.; Jubayer, A.M.; Masayuki, F.; Vasileios, F. Reactive Oxygen Species and Antioxidant Defense in Plants under Abiotic Stress: Revisiting the Crucial Role of a Universal Defense Regulator. Antioxidants 2020, 9, 681. [CrossRef]

42. Rentel, M.C.; Lecourieux, D.; Ouaked, F.; Usher, S.L.; Petersen, L.; Okamoto, H.; Knight, H.; Peck, S.C.; Grierson, C.S.; Hirt, H.; et al. Oxi1 kinase is necessary for oxidative burst-mediated signalling in Arabidopsis. Nature 2004, 427, 858-861. [CrossRef]

43. Petersen, L.N.; Ingle, R.A.; Knight, M.R.; Denby, K.J. OXI1 protein kinase is required for plant immunity against Pseudomonas syringae in Arabidopsis. J. Exp. Bot. 2009, 60, 3727-3735. [CrossRef] 